\title{
ANALISIS KEMAMPUAN PEMECAHAN MASALAH MATEMATIS SISWA SMP AL-ISMA'ILIYAH BERDASARKAN LEVEL TAKSONOMI SOLO
}

\author{
Wafa Maulidia ${ }^{1}$, Ana Setiani ${ }^{2}$, Pujia Siti Balkist ${ }^{3}$ \\ 1,2,3 Universitas Muhammadiyah Sukabumi \\ ${ }^{1}$ wafamaulidia96@gmail.com \\ 2anasetiani.math@gmail.com \\ 3 pujiabalkist@ummi.ac.id
}

\begin{abstract}
ABSTRAK
Penelitian deskriptif kualitatif bertujuan untuk mendeskripsikan kemampuan pemecahan masalah siswa berdasarkan level taksonomi SOLO pada materi Bangun Ruang Sisi Datar Kubus dan Balok. Subjek penelitian ini dilakukan pada kelas VIII C SMP Al-Isma'iliyah pada tahun ajar 2018/2019 sebanyak 28 siswa dengan menggunakan teknik purposive sampling. Instrumen tes dalam penelitian ini berbentuk soal uraian (essay) sebanyak 3 soal untuk mengetahui kemampuan siswa dalam pemecahan masalah berdasarkan level taksonomi SOLO. Instrumen tes sebelumnya telah divalidasi terlebih dahulu oleh 3 validator dan sudah diuji cobakan. Pengumpulan data yang digunakan diantaranya tes kemampuan pemecahan masalah, wawancara. Analisis data yang digunakan diantaranya reduksi data, penyajian data dan menarik kesimpulan. validasi data digunakan dengan cara triangulasi data yaitu membandngkan dari hasil tes pemecahan masalah dengan hasil wawancara, Adapun indikator-indikator kemampuan pemecahan masalah berdasarkan level taksonomi SOLO diantaranya level unistruktural, level multistruktural, level relasional dan level extended abstrak. Berdasarkan hasil tes dan wawancara subjek dengan kemampuan tinggi berdasarkan taksonomi SOLO memiliki presentase $100 \%$ mencapai level extended abstrak. Subjek dengan kemampuan sedang berdasarkan taksonomi SOLO memiliki presentase $66.67 \%$ mencapai level relasional. Subjek kemampuan rendah berdasarkan taksonomi SOLO memiliki presentase $41.67 \%$ mencapai level multistruktural.
\end{abstract}

Kata Kunci : taksonomi SOLO, kemampuan pemecahan masalah.

\begin{abstract}
Qualitative descriptive research aims to describe students' problem solving abilities based on the taxonomic level of SOLO in the material of Building Flat-Side Cubes and Beams. The subject of this study was conducted in class VIII of Al-Isma'iliyah Middle School in the 2018/2019 academic year as many as 28 students using purposive sampling technique. The test instrument in this study is in the form of a description question (essay) as many as 3 questions to determine the students' abilities in problem solving based on SOLO taxonomy level. The test instrument was previously validated by 3 validators and has been tested. Data collection used included tests of problem solving abilities, interviews. Analysis of the data used includes data reduction, data presentation and drawing conclusions. Data validation is used by means of data triangulation, namely comparing the results of problem solving tests with the results of interviews, The indicators of problem solving abilities based on SOLO taxonomy levels include unstructural levels, multistructural levels, relational levels and extended abstract levels. Based on the results of tests and interviews of subjects with high ability based on taxonomy SOLO has a percentage of $100 \%$ reaching the extended abstract level. Subjects with moderate ability based on SOLO taxonomy have a percentage of $66.67 \%$ reaching the relational level. Low ability subjects based on SOLO taxonomy have a percentage of $41.67 \%$ reaching multistructural levels.
\end{abstract}


Keywords: SOLO taxonomy, problem solving ability.

\section{PENDAHULUAN}

Kurikulum di sekolah sebagai program suatu rencana atau perangkat pembelajaran yang digunakan untuk proses berlangsungnya pembelajaran serta dapat digunakan untuk evaluasi dalam proses pembelajaran antara siswa dan guru. Berdasarkan Sistem Pendidikan Nasional Djadjuri (2015) menyatakan bahwa kurikulum adalah seperangkat rencana dan pengaturan mengenai tujuan, isi, dan bahan pelajaran serta cara yang digunakan sebagai pedoman penyelenggaraan kegiatan pembelajaran untuk pencapaian kegiatan pembelajaran tertentu.

Matematika sarana untuk berpikir logis dan jelas dalam memecahkan masalah kehidupan sehari-hari, matematika juga suatu alat komunikasi yang digunakan untuk bahasa mengisyaratkan yang dapat digunakan dalam memecahkan suatu masalah. Dimyati (dalam Susanto, 2013) Pembelajaran adalah kegiatan guru secara terprogram dalam desain intruksional, untuk membuat siswa belajar secara aktif, yang menekankan pada penyediaan sumber belajar. Berdasarkan Permendikbud No 21 tahun 2016 tentang standar isi pendidikan dasar dan menengah, salah satu kompetensi yang akan diraih pada proses belajar matematika yaitu kemampuan pemecahan masalah. Kemampuan pemecahan masalah merupakan kemampuan yang tercantum dalam kurikulum dan tujuan pembelajaran matematika, siswa juga dilatih untuk berpikir kreatif, logis, kritis, analitis dan sistematis dalam pemecahan masalah matematika. Menurut Prabawa dan Zaenuri (2017) pemecahan masalah memiliki esensi, peran yang penting dalam kompetensi pelaksanaan proses belajar mengajar matematika.

Setiap siswa memiliki kemampuan pemecahan masalah matematika yang berbedabeda antara siswa dengan siswa lainnya. Indrawati (2017) menyatakan bahwa setiap masalah memerlukan penyelesaian dan kemampuan pemecahan matematis adanya ketergantungan dengan masalah yang terdapat di dalam matematika. Suatu masalah adalah tidak kemampuannya siswa dalam menyelesaikan soal matematika dan masalah juga mempunyai suaatu tujuan untuk penyelesaian dalam memecahkan suatu masalah. Menurut Indrawati (2017) menyatakan bahwa masalah adalah pertanyaan soal yang harus dijawab dan direspon oleh siswa, dalam hal ini tidak semua pertanyaan suatu masalah. Suatu pertanyaan dikatakan masalah jika ditunjukkan adanya suatu tantangan (challengge) yang tidak dapat dipecahkan dengan suatu prosedur yang rutin (routine procedur) yang sudah diketahui oleh siswa. 
Siswono (dalam Indrawati, 2017) menjelaskan bahwa pemecahan masalah adalah suatu proses atau upaya siswa untuk merespon atau memberikan jawaban dari permasalahan yang diberikan dalam bentuk soal. Dijelaskan oleh Susanto (2013) menyatakan bahwa pemecahan masalah adalah proses diterapkan pengetahuan (knowledge) yang telah diperoleh siswa sebelumnya ke dalam situasi yang baru. Dengan demikian pemecahan masalah yaitu kemampuan siswa untuk melakukan proses pengetahuan yang sudah diketahui atau diperoleh siswa sebelumnya ke dalam hal yang baru berupa soal dan bisa berkaitan dalam masalah kehidupan sehari-hari.Killen (dalam Susanto, 2013) menyatakan bahwa pemecahan masalah sebagai strategi pembelajaran yaitu suatu teknik dimana masalah digunakan secara langsung sebagai alat untuk membantu siswa memahami materi pelajaran yang sedang mereka pelajari.

Salah satu cara guru untuk evaluasi dan mengetahui kemampuan siswa dalam pemecahan masalah bisa menggunakan taksonomi SOLO. Taksonomi SOLO digunakan untuk mengetahui respon siswa dalam kemampuan pemecahan masalah sesuai dengan tingkatannya yaitu, level prasstruktural, level unistruktural, level multistruktural, level relasional, dan level extended abstrak. Berdasarkan level taksonomi SOLO, kemampuan siswa bisa diukur melalui tingkata-tingkatan tersebut dengan membuat suatu soal pemecahan masalah dari yang mudah sampai dengan yang sulit. Adapun penjelasan dari masing-masing tingkatan taksonomi SOLO oleh Pesona (dalam Azizah, 2017), Prastruktural adalah kemampuan siswa yang tidak melibatkan suatu informasi untuk meyelesaikan suatu permasalahan. Unistruktural adalah suatu kemampuan siswa yang hanya satu informasi saja yang dapat digunakannya tetapi sudah mendapatkan hasil atau penyelesaian. Multistruktural adalah kemampuan siswa yang dua atau lebih informasi yang bisa dikaitkan untuk mendapatkan penyelesaian suatu pemecahan masalah dan bisa digunakan suatu rumus yang saling berkaitan satu sama lain. Relasional adalah kemampuan siswa dalam menggunakan dua informasi atau lebih tidak secara langsung saling berkaitan denan satu sama lain tetapi bisa menggunakan cara baru untuk bisa mendapatkan hasil atau penyelesaian. Extended Abstrak adalah kemampuan siswa yang menggunakan suatu informasi yang abstrak dari suatu soal dan bisa mendapatkan informasi baru dari suatu permasalahan untuk bisa mendapatkan hasil atau penyelesaian.

Materi untuk mengetahui kemampuan pemecahan masalah siswa salah satunya pada materi bangun ruang sisi datar kubus dan balok. Dalam materi tersebut kita bisa membuat soal pemecahan masalah dengan tingkatan soal dari yang paling mudah sampai yang sulit sesuai dengan tingkatan taksonomi SOLO. Bentuk soal yang dibuat untuk mengetahui 
kemampuan siswa tersebut, jika soal yang diberikan tingkat kemampuannya tinggi bisa diselesaikan maka kemampuan siswa tersebut dalam pemecahan matematikanya tinggi pula atau mencapai tingkatan taksonomi SOLO level extended abstrak. Sedangkan jika soal yang diberikan tinggkat kemampuannya rendah maka siswa tersebut kemampuan pemecahan matematikanya rendah pula atau tingkat taksonomi SOLO level unistruktural. Dari pemaparan diatas, peneliti tertarik untuk meneliti dengan judul "Analisis Kemampuan Pemecahan Masalah Matematika Siswa Berdasarkan Taksonomi SOLO”.

\section{METODE PENELITIAN}

Jenis metode deskriftif kualitatif akan menggambarkan suatu objek alamiah dalam soal pemecahan masalah matematika pada materi Bangun Ruang Sisi Datar Kubus dan Balok. Dari hasil penelitian kemampuan pemecahan masalah dapat dideskriptifkan berdasarkan apa yang didapat dari penelitian bisa berupa lisan maupun tulisan. Menggunakan metode kualitatif diharapkan data yang diterima bisa membantu untuk menganalis kemampuan pemecahan masalah matematika siswa berdasarkan level taksonomi SOLO pada materi Bangun Ruang Sisi Datar Kubus dan Balok. Pada penelitian ini subjek yang diambil adalah kelas VIII C SMP Al-Isma'iliyah tahun ajaran 2018/2019. Sugiyono (2016) menyatakan bahwa subjek yang diambil menggunakan teknik purposive sampling, teknik ini merupakan teknik atau sumber data dengan pertimbangan tertentu. Dalam penelitian ini subjek yang diambil sebanyak 6 siswa dari hasil tes soal kemampuan pemecahan masalah berdasarkan indikator taksonomi SOLO. Subjek yang mengikuti tes sebanyak 28 siswa. Selanjutnya dari setiap kelompok diambil masing-masing 2 subjek yang mempunyai kategori tinggi, 2 subjek kategori sedang dan 2 subjek kategori rendah. Menurut Arikunto (dalam Fitri et al, 2018) pengelompokan subjek dalam ketegori tinggi, sedang dan rendah menggunakan hasil rerata dan standar sebagai berikut :

Tabel 1. Kriteria Kemampuan Matematika Siswa

\begin{tabular}{cc}
\hline Nilai & Kriteria \\
\hline Nilai $\geq 73$ & Tinggi \\
45 Nilai $<73$ & Sedang \\
Nilai $<45$ & Rendah \\
\hline
\end{tabular}

Instrumen dalan penelitian adalah penelitian itu sendiri. Ibrahim (2018) menyatakan bahwa instrumen merupakan alat-alat yang digunakan dalam penelitian, baik alat yang melekat dalam peran seorang peneliti yang disebut instrumen utama (key instrument), maupun alat yang terpisah dengan peneliti, yang bersifat keras (hard instrument) dan yang bersifat lunak (soft instrumen). Instrumen tes dalam penelitian ini berbentuk soal uraian 
(essay) sebanyak 3 soal materi bangun ruang sisi datar pada balok dan kubus berdasarkan taksonomi SOLO. Soal tes tersebut berisi soal-soal yang berkaitan dengan kompetensi inti dan kompetensi dasar pada materi bangun ruang sisi datar pada kubus dan balok.

Teknik pengumpulan data merupakan langkah yang paling strategis dalam penelitian, karena tujuan utama dari penelitian adalah mendapatkan data. Ada beberapa macam teknik pengumpulan data yang dilakukan dalam penelitian ini diantaranya: observasi, tes, wawancara dan dokumentasi. Observasi yang dilakukan dalam penelitian ini bertujuan untuk mengamati kegiatan siswa dalam proses belajar. Peneliti ingin melihat respon siswa dan keaktifan siswa dalam kegiatan belajar di kelas VIII C. Tes yang dilakukan kepada siswa kelas VIII C SMP Al-Isma'iliyah sebanyak 3 butir soal. soal yang diberikan berupa soalsoal pemecahan masalah matematika pada materi bangun ruang sisi datar pada kubus dan balok. Soal-soal tersebut sudah sesuai dengan kompetensi inti dan kompetensi dasar pada materi bangun ruang sisi datar kubus dan balok dan disesuikan dengan indikator-indikator kemampuan pemecahan masalah berdasarkan taksonomi SOLO. Teknik pengumpulan yang dilakukan dengan wawancara kepada subjek yang dipilih untuk memperkuat hasil data kerja siswa dalam instrumen tes. Dokumentasi yang perlu dalam penelitian ini diantaranya foto kegiatan uji coba instrumen tes, kegiatan proses belajar siswa, foto kegiatan pelaksanaan tes soal, foto kegiatan wawancara peneliti dengan subjek yang sudah dipilih, data-data siswa yang akan diikut sertakan dalam penelitian, dan hasil kerja subjek pada intrumen tes yang sudah dikerjakan.

\section{HASIL DAN PEMBAHASAN}

Berdasarkan hasil analisis dari hasil jawaban siswa, kemampuan pencapaian setiap subjek berbeda-beda berdasarkan kemampuan masing-masing. Pada kemampuan pemecahan masalah siswa berdasarkan level taksonomi SOLO meliputi beberapa indikator diantaranya level unistruktural, level multistruktural, level relasional dan level extended abstrak.. Untuk lebih jelasnya dapat dilihat di diagram presentase kemampuan pemecahan masalah berdasarkan taksonomi SOLO sesuai pencapaian setiap subjek sebagai berikut: 


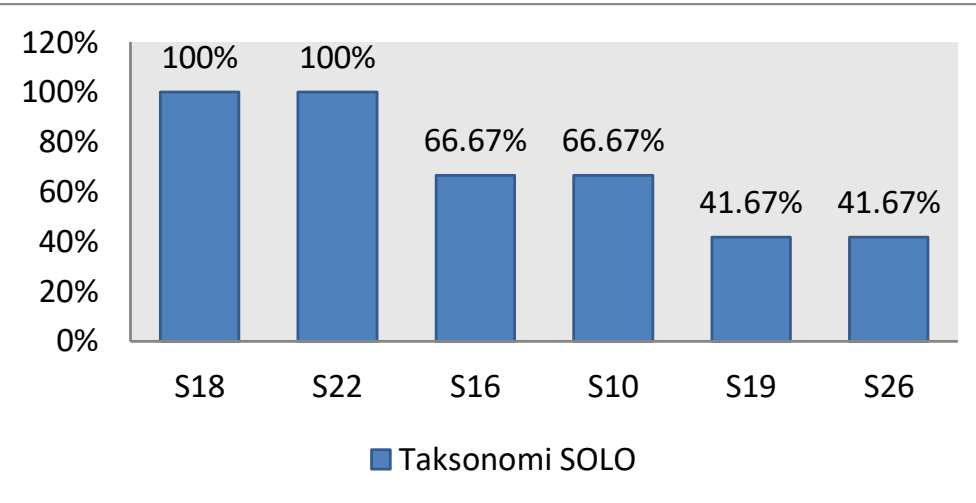

Gambar 1. Presentase Kemampuan Pemecahan Masalah Berdasarkan Taksonomi SOLO

Dari diagram diatas terdapat hasil kemampuan pemecahan masalah matematika berdasarkan taksonomi SOLO dengan presentase sesuai kemampuan masing-masing dari setiap indikator taksonomi SOLO. Subjek dengan kemampuan tinggi S18 dan S22 memiliki presentase $100 \%$ mencapai indikator taksonomi SOLO level extended abstrak, subjek dengan kemampuan sedang S16 dan S10 memiliki presentase $66.67 \%$ mencapai indikator taksonomi SOLO level relasional, subjek dengan kemampuan rendah S19 dan S26 memiliki presentase $41.67 \%$ mencapai indikator taksonomi SOLO level multistruktural.

Pada level unistruktural, subjek dengan dengan kemampuan tinggi, sedang dan rendah dapat mencapai level tersebut. Subjek dengan kemampuan tinggi dapat menuliskan informasi hal yang diketahui dan yang ditanyakan menggunakan bahasa sendiri untuk mempermudah menyelesaikan masalah selanjutnya pada level multistruktural. Sedangkan subjek dengan kemampuan sedang dan kemampuan rendah menuliskan informasi yang diketahui dan yang ditanyakan sesuai dengan soal.

Pada level multistruktural, subjek dengan kemampuan tinggi dan kemampuan sedang dapat mencapai level multistruktural pada setiap soal dengan menyelesaiakan masalah menggunakan strategi penyelesaian sesuai dengan hal diketahui untuk mendapatkan hasil yang digunakan pada langkah selanjutnya. Sedangkan subjek kemampuan hanya soal nomor 1 dan 2 saja yang mencapai level multistruktural. Pada soal nomor 3 subjek hanya bisa menuliskan informasi yang digunakan tidak mengaplikasikan kembali untuk mendapatkan hasil selanjutnya untuk menarik kesimpulan. Subjek dengan kemapuan rendah mencapai level multistruktural di nomor satu dan dua saja, untuk soal nomor 3 subjek kemampuan rendah menuliskan informasi yang didapat tanpa menyelesaikan dan tidak dapat menarik kesimpulan.

Pada level Relasional Subjek berkemampuan tinggi dapat menyelesaikan pada setiap soal dengan menggabungkan dua informasi dari hasil sebelumnya sampai mendapatkan hasil 
jawaban. Tetapi subjek pada penyelesaian kurang tepat mengoperasikan bagi yang hasil desimal diakibatkan hasil kurang tepat. Pada subjek kemampuan sedang dapat menyelesaikan dengan menggabungkan dua hasil sebelumnya untuk mendapatkan jawaban untuk bisa diaplikasikan pada langkah selanjutnya. Subjek kemampuan rendah tidak dapat menyelesaikan pada tahap ini dari ketiga soal dengan demikian sabjek kemampuan rendah tidak mencapai level relasional.

Pada level extended abstrak subjek berkemampuan tinggi dapat menambahkan informasi baru untuk diaplikasikan dengan hasil sebelumnya dan mendapatkan jawaban sesuai dengan yang ditanyakan untuk menarik kesimpulan. Subjek kemampuan tinggi mencapai level extended abstrak berdasarkan taksonomi SOLO. Sesuai dengan penelitian Pesona (2018) menyatakan bahwa siswa dengan kemampuan matematika tinggi, mampu mengerjakan dengan benar siswa tersebut dapat mampu mengerjakan sampai level extended abstrak. Subjek berkemampuan sedang dan rendah tidak dapat menyelesaikan ataupun menambahkan informasi baru untuk mendapatkan hasil untuk menarik kesimpulan. Dengan demikian pada level extended abtrak hanya mampu tercapai oleh kemampuan tinggi saja.

Adapun hasil analisis kemampuan pemecahan masalah matematika berdasarkan taksonomi SOLO dengan subjek kemampuan tinggi (S18, S22), kemampuan sedang (S16, S10) dan kemampuan rendah (S19, S26) pada ketiga soal mencapai level berbeda-beda. Berikut ini hasil analisis kemampuan pemecahan masalah matematika berdasarkan taksonomi SOLO pada soal nomor satu:

\section{Sola Nomor 1:}

1. Guru matematika memberikan tugas praktek kepada siswa kelas VIII SMP untuk membuat sebuah kerangka berbentuk kubus. Salah satu siswa yang bernama Hilal akan membuat kerangka tersebut dari kawat yang berukuran panjang 10 meter. Jika kerangka kubus yang harus dibuat berukuran $30 \mathrm{~cm}$. Tentukanlah:

a. Berapakah panjang kawat yang dibutuhkan Hilal untuk membuat satu buah kerangka kubus?

b. Berapakah banyak kerangka kubus yang akan dibuat Hilal dengan kawat yang dimilikinya?

c. Berapakah sisa kawat yang dilakukan Hilal dari pembuatan kerangka kubus tersebut? 


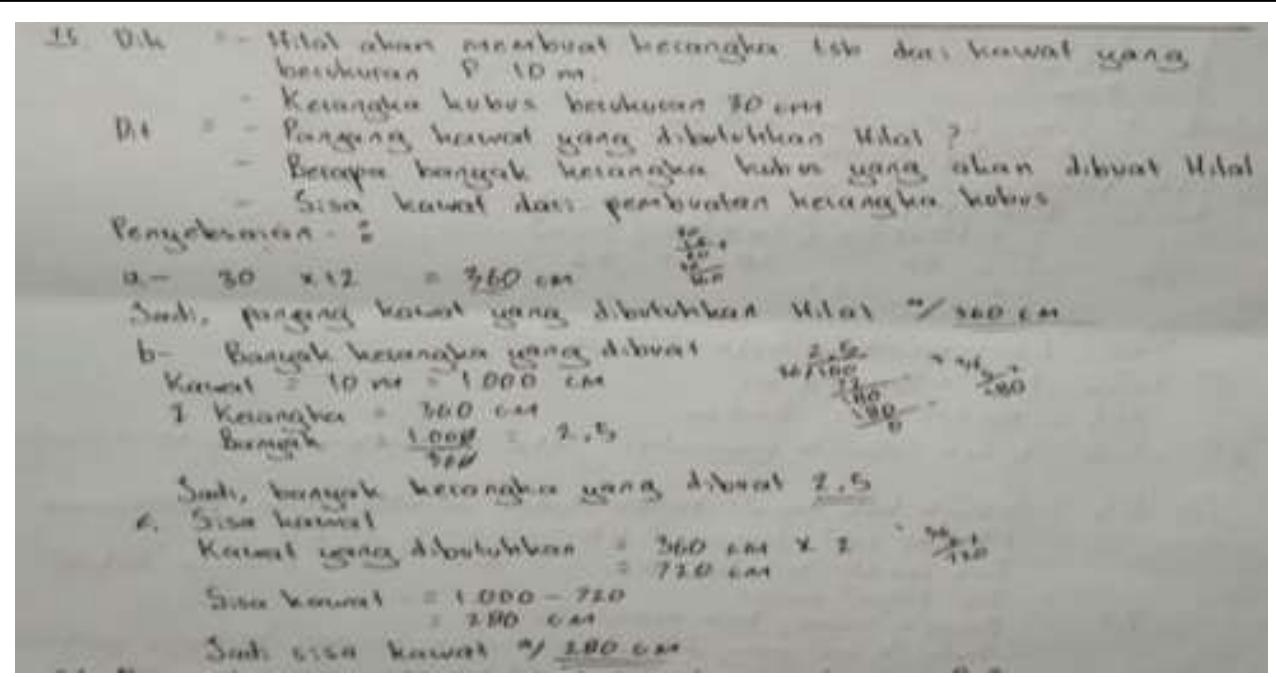

Gambar 2. Jawaban Subjek S18

Berdasarkan hasil lembar jawaban subjek S18 soal nomor satu pada Gambar 2 kemampuan pemecahan masalah mencapai level extended abstrak pada taksonomi SOLO dengan presentase $100 \%$. Subjek pada level unistruktural menuliskan informsi yang digunakan untuk merencanakan penyelesaian dengan menuliskan hal yang diketahui dan hal yang ditanyakan. Level multistruktural subjek S18 menggunakan informasi yang diketahui untuk menarik kesimpulan. Level relasional subjek S18 menyelesaikan masalah menggunakan informasi dari hasil sebelumnya dengan informasi yang diketahui selajutnya diaplikasikan sampai menarik kesimpulan tetapi hasil kurang tepat dikarenakan kurang paham dalam operasi bagi hasil desimal. Pada level terakhir level extended abstrak subjek menyelesaikan dengan menghubungkan informasi sebelumnya dan menambahkan hasil baru untuk dapat menarik kesimpulan.

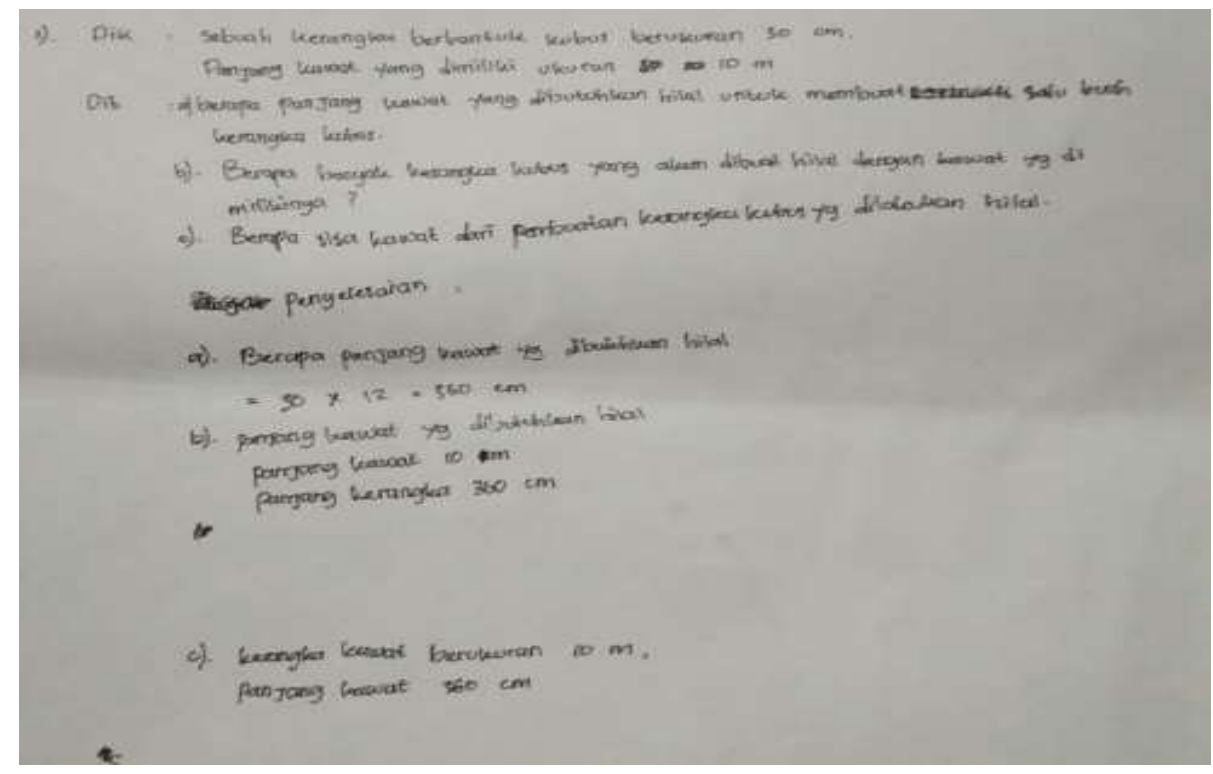

Gambar 2. Jawaban Subjek S16 


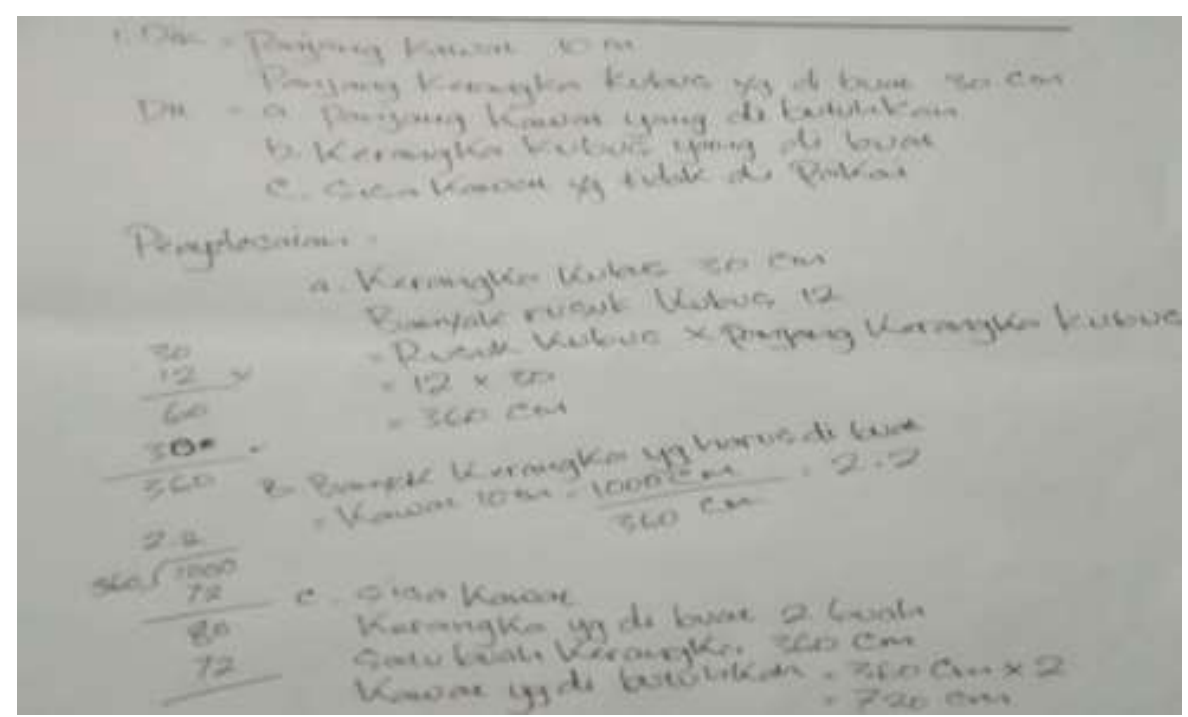

Gambar 3. Jawaban Subjek S16 (lanjutan)

Berdasarkan hasil lembar jawaban subjek S16 soal nomor satu pada Gambar 3 kemampuan pemecahan masalah mencapai level relasional pada taksonomi SOLO dengan presentase $66.67 \%$. level unistruktural Subjek S16 menggunakan informasi yang diketahui dan yang ditanyakan untuk menarik kesimpulan. level multistruktural subjek S16 menyelesaikan masalah dengan menggunakan informasi yang diketahui untuk menarik kesimpulan. Level relasional subjek S16 menyelesaikan masalah dengan menggunakan informasi dari hasil sebelumnya dengan informasi yang diketahui dan diaplikasikan untuk menarik kesimpulan. Level extended abstrak subjek S16 tidak dapat menghubungkan informasi dengan informasi baru dan tidak bisa menarik kesimpulan.

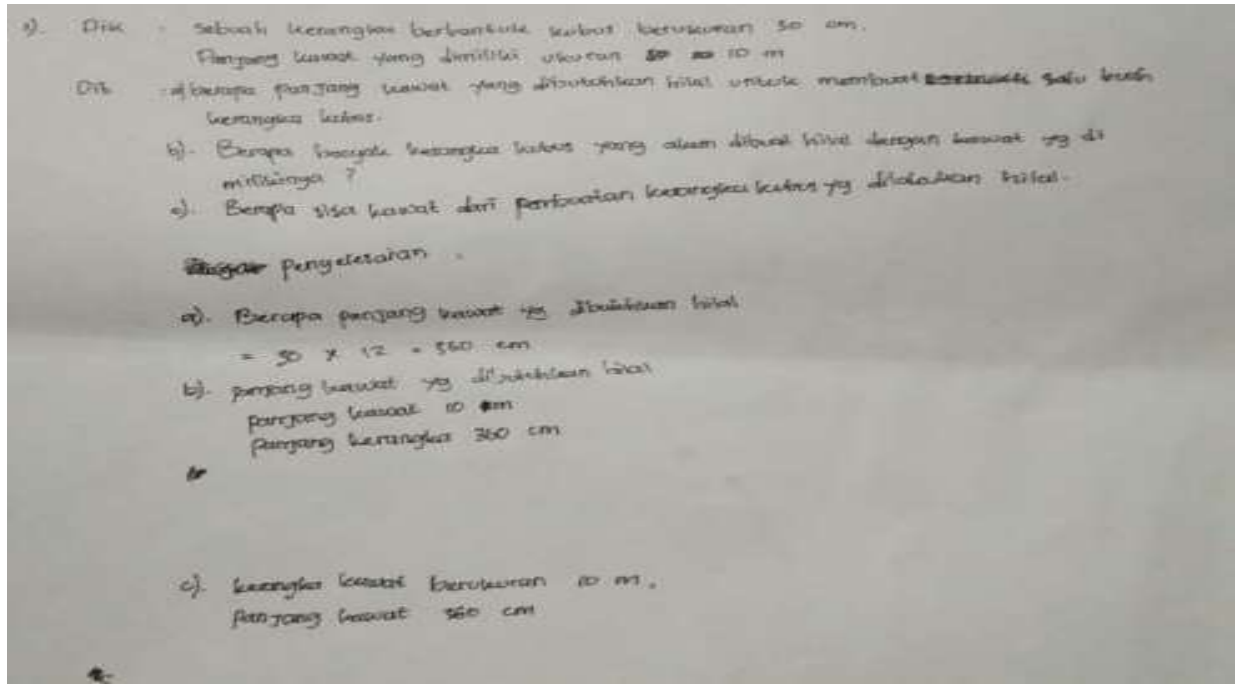

Gambar 4. Jawaban Subjek S26

Berdasarkan hasil lembar jawaban subjek S26 soal nomor 1 pada Gambar 4 kemampuan pemecahan masalah mencapai level relasional pada taksonomi SOLO dengan presentase $41.67 \%$. Level unistruktural subjek S26 menyelesaikan masalah dengan 
menuliskan informasi yang diketahui dan yang ditanyakan sesuai dengan soal. Level multistruktural subjek S26 menyelesaikan masalah dengan menggunakan informasi yang terdapat dalam soal untuk menarik kesimpulan. Level relasional dan level extended abstrak subjek S26 tidak menyelesaiakan masalah tidak menghubungkan hasil sebelumnya dengan informasi yang diketahui dengan demikian subjek tidak mencapai level tersebut.

\section{KESIMPULAN}

Berdasarkan pembahasan dan analisis hasil lembar jawaban siswa kelas VIII SMP Al-Isma'iliyah tahun ajaran 2018/2019 pada materi bangun ruang sisi datar. Kemampuan pemecahan masalah matematika berdasarkan taksonomi SOLO mencapai beberapa indikator - indikator sebagai berikut: 1) Level Unistruktural 2) Level Multistruktural 3) Level Relasional 4) Level Extended Abstrak. Kemampuan subjek berdasarkan kemampuan tinggi, sedang dan rendah memiliki perbedaan setiap kemapuan.

Kemampuan pemecahan masalah siswa berdasarkan level taksonomi SOLO, kemampuan tinggi mencapai level extended abstrak, kemampuan sedang mencapai level relasional, sedangkan kemampuan rendah mencapai level multistruktural. Adapun kesimpulan setiap kemampuan sebagai berikut: 1) kemampuan tinggi mencapai level extended abstrak dengan presentase 100\%, subjek dapat menyelesaikan masalah dengan menambahkan informasi baru diaplikasikan dengan hasil sebelumnya untuk menarik kesimpulan. 2) Kemampuan sedang mencapai level relasional dengan presentase $66.67 \%$, subjek menyelesaikan masalah dengan menghubungkan informasi sebelumnya diaplikasikan dengan informasi yang diketahui untuk menarik kesimpulan. 3) Kemampuan rendah mencapai level multistruktural dengan presentse $41.67 \%$, subjek dapat menyelesaikan masalah dengan mengaplikasikan informasi yang diketahui untuk menarik kesimpulan.

\section{REKOMENDASI}

Pada penelitian ini ada kekurangan untuk pihak guru dan peneliti yaitu (1) Kepada guru, dalam pelaksanaan proses belajar guru harus mengetahui kemampuan pemecahan masalah matematika seperti taksonomi SOLO. Guru harus membedakan siswa dalam mengajar yang berkemamuan tinggi ataupun remdsh; (2) Kepada peneliti, dalam penelitian ini masih banyak kekurangan karena subjek yang diambi hanya 6 subjek yang dibagi dalam 3 kategori. Dalam penelitian ini tidak hanya pada materi bangun ruang saja tetapi dalam materi matematika apa saja. 


\section{UCAPAN TERIMAKASIH}

Terimakasih kepada pihak-pihak tertentu yang sudah membantu dalam penelitian ini.

\section{REFERENSI}

Djajuri, D., Sepuloh, S., dan Rizal,. S.U, (2015). Kurikulum dan Pembelajaran (jilid 1 Kurikulum). Kota Bekasi: CV. Nurani.

Ibrahim. (2018). Metodologi Penelitian Kualitatif. Bandung: Alfabeta CV.

Indriyani, F. Novi, A N. Nur Agustiani, (2018). Analisis Kemampuan Pemecahan Masalah Siswa Berdasarkan Langkah Ideal Problem Solving. "Pythagoras. ”7(2), 56-67.

Indrawati, R. (2017). Profil Pemecahan Masalah Ditinjau dari Gaya Belajar. "Jurnal Preogram Pendidkan Matematika”. 3, (2), 91 - 100.

Pesona,I,K. (2018). Deskripsi kemampuan matematika siswa dalam pemecahan masalah sistem persamaan linesar dua variabel berdasarkan level taksomi SOLO. "GENTA MULIA ".IX (9), 99-109.

Prabawa, E.A dan Zaenuri. (2017). "Analisis Kemampuan Pemecahan Masalah Dari Gaya Kognitif Siswa pada Model Project Based Learning Benuansa Etnomatematika". “Unnes Journal of Mathematics Education Research". 6, (1), 120 - 129.

Sugiyono. (2016). Metode Penelitian Kuantitatif, Kualitatif, dan R\&D. Bandung: Alfabeta. Susanto, A. (2015). Teori Belajar Pembelajaran di Sekolah Dasar. Jakarta: Prenadamedia Group. 